\title{
The Blood Libel in Eastern Europe
}

\author{
ROBERT WEINBERG \\ Swarthmore College, Swarthmore, PA, USA \\ E-mail: rweinbe1@swarthmore.edu
}

Keywords Antisemitism $\cdot$ Blood libel $\cdot$ Kiev $\cdot$ Mendel Beilis $\cdot$ Russian Empire

This issue of Jewish History explores the phenomenon of "blood libel" in eastern Europe in the nineteenth and twentieth centuries. The accusation that Jews murder Christians, particularly young boys and girls, for ritual purposes has a long and lurid lineage that dates back to the Middle Ages. ${ }^{1}$ The accusation of ritual murder emerged in England in the mid-twelfth century with the charge that Jews had killed a Christian youth in order to mock the Passion of Christ. By the middle of the thirteenth century the belief that Jews killed Christians had spread to the European continent, where gentiles now accused Jews of desecrating the Host and using gentile blood for religious purposes, including consuming it in matzo. The charge of ritual murder gained strength in the wake of the Fourth Lateran Council, held in 1215, when the Western Christian church affirmed that the wafer and wine used in the sacrament of the Eucharist contained the body and blood of Christ. According to some historians, the belief that Christians consumed the blood and flesh of their savior during weekly communion - the doctrine of transubstantiation-prompted many believers to project onto Jews their own guilt over ritual cannibalism. ${ }^{2}$

Church officials in Rome issued numerous papal bulls that rejected the notion of blood libel, asserting that Jews did not engage in Host desecration or use gentile blood for the baking of matzo. But the Vatican had difficulty

\footnotetext{
${ }^{1}$ The Romans accused early Christians but not Jews of practicing ritual murder. In the second century BCE, however, King Antiochus IV accused Jews of eating Greek captives. Thereafter, the accusation of Jewish cannibalism remained dormant until its appearance in England many centuries later, when it acquired a religious underpinning.

${ }^{2} \mathrm{~A}$ useful overview of the ritual murder accusation, or blood libel, can be found in Helmut Walser Smith, The Butcher's Tale: Murder and Anti-Semitism in a German Town (New York, 2002), 91-133. See also Joshua Trachtenberg, The Devil and the Jews: The Medieval Conception of the Jew and Its Relation to Modern Anti-Semitism (New Haven, CT, 1943); Alan Dundes, ed., The Blood Libel Legend: A Casebook in Anti-Semitic Folklore (Madison, WI, 1991); R. Po-chia Hsia, The Myth of Ritual Murder: Jews and Magic in Reformation Germany (New Haven, CT, 1988). On the matter of ritual cannibalism, see Gavin Langmuir, Toward a Definition of Antisemitism (Berkeley, 1990), chaps. 9-13.
} 
stemming the belief among parishioners and clergy, particularly during the Passover and Easter holidays. The disappearance of a child was often sufficient to raise the cry of ritual murder, and if the child's body turned up bruised or mutilated, Jews would be arrested, tortured, and even executed by local authorities. Suspicions about the role of Jews in these alleged murders created situations in which gentiles attacked their Jewish neighbors with impunity and prompted communities to expel Jews, particularly in German-speaking Europe. The best-known case of blood libel from this time period occurred in Trent in 1475 , when a group of Jewish men and women, subjected to savage torture on the strappado, confessed to killing a two-year-old child and were then burned at the stake. ${ }^{3}$

Beginning in the sixteenth century, ritual murder accusations began to die out in western and central Europe due to several developments. The rise of Protestantism, which rejected the doctrine of transubstantiation, weakened the appeal of blood libel, as did the emergence of Christian scholars who could read Jewish texts in Hebrew. Moreover, the judiciary in Germanspeaking Europe rejected the use of coercion and torture to extract confessions, the earlier method for demonstrating the purported veracity of the blood libel. This is not to deny that some Protestant theologians and intellectuals continued to believe in ritual murder, but on the whole the blood libel tended to hold sway in Catholic Europe-particularly in the Catholic regions of the Polish-Lithuanian Commonwealth, where the bulk of Europe's Jews lived by the seventeenth century. ${ }^{4}$ Recent research by scholars such as Paweł Maciejko, Zenon Guldon, Jacek Wijaczka, Hanna Węgrzynek, Daniel Tollet, and Jurgita Šiaučiūnaitè-Verbickienè highlight the blood libel's hold on the imagination of Catholic clergy and laity in eastern Europe during the centuries when it was declining in territories to the west. ${ }^{5}$

\footnotetext{
${ }^{3}$ R. Po-Chia Hsia, Trent 1475: Stories of a Ritual Murder Trial (New Haven, CT, 1992).

${ }^{4}$ As Walser Smith notes (Butcher's Tale, 107), Protestants in German-speaking Europe were prone to reject the ritual murder charge over time, while "the idea of ritual murder retained more of a hold" on Catholics in central and eastern Europe.

${ }^{5}$ Paweł Maciejko, "Christian Accusations of Jewish Human Sacrifice in Early Modern Poland: The Case of Jan Serafnowicz," Gal-Ed 22 (2010): 15-66; Zenon Guldon and Jacek Wijaczka, Procesy o mordy rytualne w Polsce w XVI-XVIII wieku (Kielce, 1995); Hanna Węgrzynek, 'Czarna legenda' Zydów: Procesy o rzekome mordy rytualne w dawney Polsce (Warsaw, 1995); Daniel Tollet, Accuser pour convertir: Du bon usage de l'accusation de crime ritual dans la Pologne catholique à l'époque moderne (Paris, 2000); Jurgita ŠiaučiūnaitèVerbickiené, "Blood Libel in a Multi-Confessional Society: The Case of the Grand Duchy of Lithuania," East European Jewish Affairs 38, no. 2 (2008): 201-9; Jacek Wijaczka, "Ritual Murder Accusations in Poland throughout the 16th to 18th Centuries," in Ritual Murder: Legend in European History, ed. Susanna Buttaroni and Andrzej Bialko (Kraków, 2003), 195-209.
} 
In the nineteenth century the ritual murder accusation experienced a renascence, culminating in seventy-nine ritual murder charges in the last decade of the century. The majority of these cases took place in Germany and parts of the Habsburg Empire such as Hungary, Bohemia, and Moravia, as well as in Bulgaria, the Russian Empire, Serbia, and Romania; Protestants, Catholics, and Orthodox alike were involved. ${ }^{6}$ Nor was the blood libel limited to Europe. As Robert Rockaway and Arnon Gutfeld have noted, the ritual murder myth was embraced in some segments of American society in the nineteenth century as well. ${ }^{7}$

At first glance, the appearance of the blood libel in the Russian Empire is difficult to explain. The Orthodox Christian tradition did not share the Roman Catholic Church's fixation on ritual murder. In addition, Jews had not been allowed to reside in Russia until the second half of the eighteenth century. But large numbers of Jews, Catholics, and Uniates (Greek Catholics who acknowledge papal authority and doctrine but retain many Eastern Orthodox rites and rituals) became imperial subjects as a result of the partitions of Poland in the late eighteenth century. By the mid-1790s Catherine the Great found herself ruler of nearly one million Jews and some five million Catholics and Uniates, all of whom resided in the western and northwestern borderlands of the empire (Belarus, Ukraine, and Lithuania) where the blood libel had deep roots in the popular culture and politics of the region. Over the course of the nineteenth century the Orthodox inhabitants of the Russian Empire embraced the ritual murder accusation, though the process by which the blood libel was disseminated has yet to be explicated. ${ }^{8}$ Along with rumors that did not lead to official charges, investigations and trials of Jews accused of engaging in ritual murder took place in Velizh in the 1820s and 1830s, Saratov in the 1850s, and Kutaisi, Georgia, in 1879.

The best-known case of blood libel took place in Kiev in October 1913, when Mendel Beilis, the Jewish manager of a brick factory, stood trial for the murder of twelve-year-old Andrei Iushchinskii two years earlier. Unlike most blood libel cases that came before it, the Beilis affair depended upon the active involvement of the state. A small group of police and judicial officials, including the minister of justice, conspired to frame Beilis, despite the existence of evidence that pointed to a gang of thieves as the murderers. Beilis

\footnotetext{
${ }^{6}$ Walser Smith, Butcher's Tale, 123.

${ }^{7}$ Robert Rockaway and Arnon Gutfeld, "Demonic Images of the Jew in the Nineteenth Century United States," American Jewish History 89, no. 4 (2002): 355-81.

${ }^{8}$ See John Klier, "The Origins of the 'Blood Libel' in Russia," Newsletter of the Study Group on Eighteenth-Century Russia 14 (1986): 12-22; Robert Weinberg, "Look! Up There in the Sky: It's a Vulture, It's a Bat ... It's a Jew," in Eugene Avrutin and Harriet Murav, eds., Jews in the East European Borderlands (Boston, 2012), 167-86.
} 
languished in prison for more than two years while the prosecution assembled a case based on perjured testimony and unsubstantiated rumors. Even the introduction of evidence that clearly contradicted the state's case against Beilis did not deter the prosecution. In the end the jury acquitted Beilis of Iushchinskii's murder, though the jurors did agree with the prosecution that the murder had the hallmarks of a ritual killing, a chilling testament to the continued belief in the blood libel among the populace in late Imperial Russia. All it would have taken to convict Beilis was a change in the vote of one juror from "not guilty" to "guilty.",

The articles in this special issue of Jewish History examine several incidents of ritual murder accusations in eastern Europe and east-central Europe-specifically, in the Habsburg Empire, the Russian Empire, the Soviet Union, and independent Poland-in the nineteenth and twentieth centuries. Collectively they touch upon a number of themes and issues integral to our understanding of the social, cultural, and political transformations that Europe was undergoing a century ago. These essays underscore how the discourse about ritual murder reflected critical developments in European society and demonstrate how the blood libel in the nineteenth and twentieth centuries differed from earlier ritual murder accusations. Two cosmologies that many observers at the time considered at odds with each other competed for the hearts and minds of Europeans: one continued to embrace the world of the supernatural, superstition, and magic, while the other was firmly rooted in the world of modern medicine and science. While in some instances the contemporary cosmology overshadowed the traditional one, in others the older one held sway, and in still others the two contrasting worldviews vied for influence. In any case, both of these distinct and contrasting ways of thinking about and apprehending the world led in their own ways to popular acceptance of the blood libel. More than just run-of-the-mill, everyday antisemitism is required to explain the prosecution of Jews for ritual murder. The blood libel, as these essays make clear, also performed an important function in the dynamics of nationalism, democratization, and mass politics.

\footnotetext{
${ }^{9}$ For an overview of the Beilis affair, see Robert Weinberg, "The Trial of Mendel Beilis: The Sources of 'Blood Libel' in Late Imperial Russia," in Russia's Century of Revolutions: Parties, People, Places; Studies Presented in Honor of Alexander Rabinowitch, ed. Michael Melancon and Donald Raleigh (Bloomington, IN, 2012), 17-35; Hans Rogger, "The Beilis Case: AntiSemitism and Politics in the Reign of Nicholas II," Slavic Review 25, no. 4 (1966): 615-29; Maurice Samuel, Blood Accusation: The Strange History of the Beilis Case (New York, 1966); G. Reznik, V. Kel'ner, R. Ganelin, and I. Lukoianov, eds., Delo Mendelia Beilisa: Materialy Chrezvychainoi sledstvennoi komissi Vremmennogo pravitel'stva o sudebnom protsesse 1913 g. po obvineniiu $v$ ritual'nom ubiistve (St. Petersburg, 1999); A. S. Tager, Tsarskaia Rossiia $i$ delo Beilisa: K istorii antsemitizma (Moscow, 1933). The trial transcript can be found in Delo Beilisa: Stenograficheskii otchet (Kiev, 1914).
} 
Still, we should not discount the importance of the persistence of folk traditions and the place that magic, superstition, and the supernatural continued to play in popular culture. It was the coexistence of two competing modes of knowledge-one considered rational and logical and the other viewed as irrational and nonscientific - that made the blood libel such an explosive issue in central and eastern Europe and that made blood libel cases in the late nineteenth and early twentieth centuries a bellwether of European modernity. ${ }^{10}$

The development of a mass-circulation press in the nineteenth century enabled the literate public to follow the cases closely as they developed and contributed in no small measure to making the events in one city, town, or village resonate throughout the country, collapsing boundaries between urban and rural eastern Europe and the Russian Empire and making informed citizens of both rural and urban dwellers. This was certainly true in the ritual murder cases that constitute the primary focus in three of the four essays included in this special issue, just as the fourth estate played critical roles in the Beilis trial and other ritual murder trials (such as the one in the town covered by Helmut Walser Smith in The Butcher's Tale: Murder and Antisemitism in a German Town). In addition, the judicial processes in the Russian and Habsburg Empires, which relied on jury trials for criminal cases, provided a public space that accommodated a variety of worldviews drawing upon religion, popular culture, science, medicine, and the supernatural. By the late nineteenth century the courtroom had become a forum for the clash of ideologies and reflected the growing politicization of public life. Government lawyers realized that the ritual murder accusation needed to be supported by evidence that met the scientific and intellectual standards of the day. Consequently, prosecutors invoked the authority of the written word and contemporary science to legitimate medieval-era views and beliefs. A modern vernacular and modern modes of argumentation thereby cloaked superstition and religious prejudice in the guise of fact and truth. As one antisemitic editorial noted about the Beilis trial, the defendants' attorneys did not permit themselves to accept that there "could be ritual murders in the century of airplanes and electric trams." 11

\footnotetext{
${ }^{10}$ The accusation of ritual murder was for the most part absent from the Arab-Muslim world, but the growing presence and influence of European Christian communities in the Middle East-Catholics, Protestants, and Orthodox alike-led to accusations of blood libel by the early nineteenth century. The best-known instance of blood libel in the Middle East occurred in Damascus in 1840, when the disappearance of an Italian monk and his Muslim servant prompted the accusation of ritual murder. Torture elicited confessions of guilt, but a delegation of prominent European Jews prevailed upon Muhammad Ali of Egypt to release the accused. Jews elsewhere in the region also found themselves the target of ritual murder accusations, which extended into the twentieth century. See Jonathan Frankel, The Damascus Affair: "Ritual Murder," Politics, and the Jews in 1840 (Cambridge, 1997).

${ }^{11}$ Russkoe znamia, no. 240 (October 25, 1913), 2.
} 
In his essay "The Rules of the Game: Forensic Medicine and the Language of Science in the Structuring of Modern Ritual Murder Trials," Hillel Kieval stresses the importance of purportedly rational and scientific evidence and argumentation in two ritual murder trials that took place in Hungary and Germany in the last two decades of the nineteenth century. He argues that while the ritual murder accusation still gripped some segments of European society in the late nineteenth century, the prosecution of such cases in the courts required the appropriation of "the authority and prestige of medical science." In his words, the "nonrational, conspiratorial thinking" that had been the popular foundation of the blood libel had fallen into disrepute and was "suppressed" by the authorities. Government officials who accused Jews of such killings instead had to draw upon more acceptable forms of contemporary knowledge such as criminology and forensics in order to fashion their cases. Even the prosecutors of Beilis relied upon forensic medicine, going so far as suppressing the original autopsy report in the hope that a second autopsy would support the ritual murder charge. ${ }^{12}$

Eugene Avrutin, in contrast, in his contribution "Ritual Murder in a Russian Border Town," focuses on the social relationships among neighbors in a tiny Belorussian village in the 1820 s and reveals how the cultural and religious universe of the peasantry influenced the way villagers perceived Jews and Judaism. In a physical and spiritual world inhabited by witches, spirits, miracle-workers, and the like, Belorussian peasants, in Avrutin's words, found nothing "strikingly peculiar about the idea that Jews required Christian blood for religious ritual services." Undoubtedly the fact that the case studied by Avrutin occurred much earlier in the nineteenth century, and in a region of the Russian Empire that was relatively untouched by currents of thought and practices found further west, helps to explain the importance in that instance of traditional values and beliefs in the behavior of both peasants and government officials.

In her contribution, "Jewish Students and Christian Corpses in Interwar Poland: Playing with the Language of Blood Libel," Natalia Aleksiun demonstrates that anti-Jewish activists adopted language and thinking closely linked to the rhetoric of the blood libel, combining "modern racial science with traditional prejudicial attitudes to argue in essence that any contact between Jews and non-Jews was dangerous, even after death." She examines the attempts in interwar Poland to prevent Jewish medical students from using Christian corpses in their anatomy labs. Antisemitic medical students and

\footnotetext{
${ }^{12}$ In the Beilis trial, for example, the prosecution resurrected medieval antisemitic canards and used the illogical and rambling writings of a Catholic priest in building its case against the defendant. On the two autopsy reports, see Samuel, Blood Accusation, 37-38, 80-84, 161, 171-72; A. S. Tager, The Decay of Czarism: The Beiliss Trial (Philadelphia, 1935), 55-59.
} 
their supporters, aware that Jewish law prohibited the desecration of Jewish corpses, hoped to keep Jews from attending medical schools since the latter would not have any cadavers to dissect. Such actions reflected a belief among antisemites that Jews threatened the country's well-being. During these same years medical students elsewhere in Eastern Europe also insisted that Jewish students obtain Jewish cadavers for dissection. In Cluj, Romania, for example, this demand "came to symbolize the sense of social and national wrong that pervaded the Romanian student body."13

Elissa Bemporad, in her essay "Empowerment, Defiance, and Demise: Jews and the Blood Libel Specter under Stalinism," explores ritual murder accusations in the Soviet Union from the 1920s to the decade following Stalin's death in 1953. In the 1920s and 1930s, Soviet authorities tended to defend Jews from these scurrilous charges, but after World War II communist officials for the most part turned a deaf ear to protests about ritual murder accusations. As Bemporad demonstrates, the blood libel "remained rooted in Soviet society in spite of the state's opposition to antisemitic prejudices." Moreover, she suggests that the ritual murder accusation underwent a secular transformation in the context of the "Doctors' Plot" allegations, a case in which Soviet physicians, mostly Jewish, were accused of conspiring to murder prominent Soviet officials. Jews were no longer charged with murdering non-Jews for religious or ritual purposes; rather, Stalin and his supporters offered a modernized image of the demonic Jew who was now targeting gentiles based on political motivations, though the goal and result were the same as before-namely, the killing of non-Jews to satisfy a lust for blood.

The blood libel is not an artifact of the past. It continues to play a role in contemporary culture, politics, and society in Europe, the Middle East, Russia, and the United States. In February 1992, shortly after the dissolution of the Soviet Union, I arrived in Moscow to conduct research in the country's main library, the Lenin Library. I noticed a small group of protestors holding signs demanding that the library hold onto a collection of books that were "a national resource" of the Russian people. As I soon learned, the demonstrators were protesting a 1991 decision of the Russian Supreme Court that ordered the Lenin Library to relinquish some twelve thousand books, nearly four hundred manuscripts in Hebrew and Yiddish, and thousands of pages of handwritten teachings, letters, and other materials that once comprised the library of the Lubavicher rebbe (Sholom Dov Ber Schneersohn), the leader of a sect of Hasidim now headquartered in Brooklyn. According to some of the protestors, Jews in the United States were clamoring to gain possession of the collection because the books and manuscripts in dispute held the secret to the

\footnotetext{
${ }^{13}$ Irina Livezeanu, Cultural Politics in Greater Romania: Regionalism, Nation Building, and Ethnic Struggle, 1918-1930 (Ithaca, NY, 1995), 269.
} 
blood libel. As one right-wing newspaper proclaimed, "Hasidic manuscripts from the Schneersohn collection ... belong to the Russian people as incontestable evidence of the ritual crimes of Talmudic Yids."14

During World War I, Schneersohn, fearing for the safety of his collection with the approach of German and Austrian troops, had sent the books to Moscow for safekeeping. Also at issue in the court case were the manuscripts and handwritten documents assembled by Yosef Yitzchak Schneersohn, who succeeded Sholom Dov Ber Schneersohn as the sixth Lubavicher rebbe. He took this part of his library to Warsaw in 1933, only to see German troops seize the collection when they occupied the city at the start of World War II. He managed to escape and made his way to the United States in 1940. Soviet troops confiscated the manuscripts as part of a German archive on Jewish affairs after the defeat of Germany.

The administration of the library refused to hand over the collection, and later in 1992 the Russian government nullified the court decision. The collection has remained in legal limbo ever since, though in 2002 the Lenin Library did transfer sixteen books to the Lubavichers after the US government returned the Smolensk Archive to Russian authorities. In 2005 the US Senate and House of Representatives signed a letter requesting Vladimir Putin to intercede in the matter and return the books and manuscripts in question. Then, in 2008, the US Court of Appeals in Washington, DC, affirmed a lower court's ruling that the Lubavicher community in Brooklyn could file suit in American courts for the return of the library. A judge ruled in 2010 that the Lubavichers were the rightful owners of the library and ordered the Russian government to relinquish the books and manuscripts. But the Russian Ministry of Foreign Affairs refused to comply with the court's decision, and as of 2012 the collection remains in Russia.

Another example of the continuing hold of the blood libel on the popular imagination involves the grave in Kiev of Andrei Iushchinskii, Beilis's purported victim, which has become a site of pilgrimage for nationalists and antisemites who view him as a martyr, the victim of a vast Jewish conspiracy to destroy the fabric of Russian and Ukrainian culture and society (see

\footnotetext{
14 “K voprosu o vydache khasidskikh rukopisei (t.n. bibliotek Schneersona i Ginstsurga), khraniashchikhsia v fondakh GBL," Zemshchina, no. 53 (1991), quoted in Konstantin Akinsha and Patricia Kennedy Grimsted, "On the Way Back: The Schneerson Collection and the Return of the 'Smolensk Archive,"' in The Return of the Smolensk Archive, ed. Marianna Tax Choldin, Ekaterina Genieva, and Patricia Kennedy Grimsted (Moscow, 2005), 232-71, quote on 244 and 267, n. 52. For an overview of the controversy, see Michael J. Bazyler and Seth M. Gerber, "Litigating the Pillage of Cultural Property in American Courts: Chabad v. Russian Federation and Lessons Learned," Loyola of Los Angeles International Comparative Law Review 45 (2010): 45-82; Michael J. Bazyler and Seth M. Gerber, "Chabad v. Russian Federation: A Case Study in the Use of American Courts to Recover Looted Cultural Property," International Journal of Cultural Property 17 (2010): 361-86.
} 


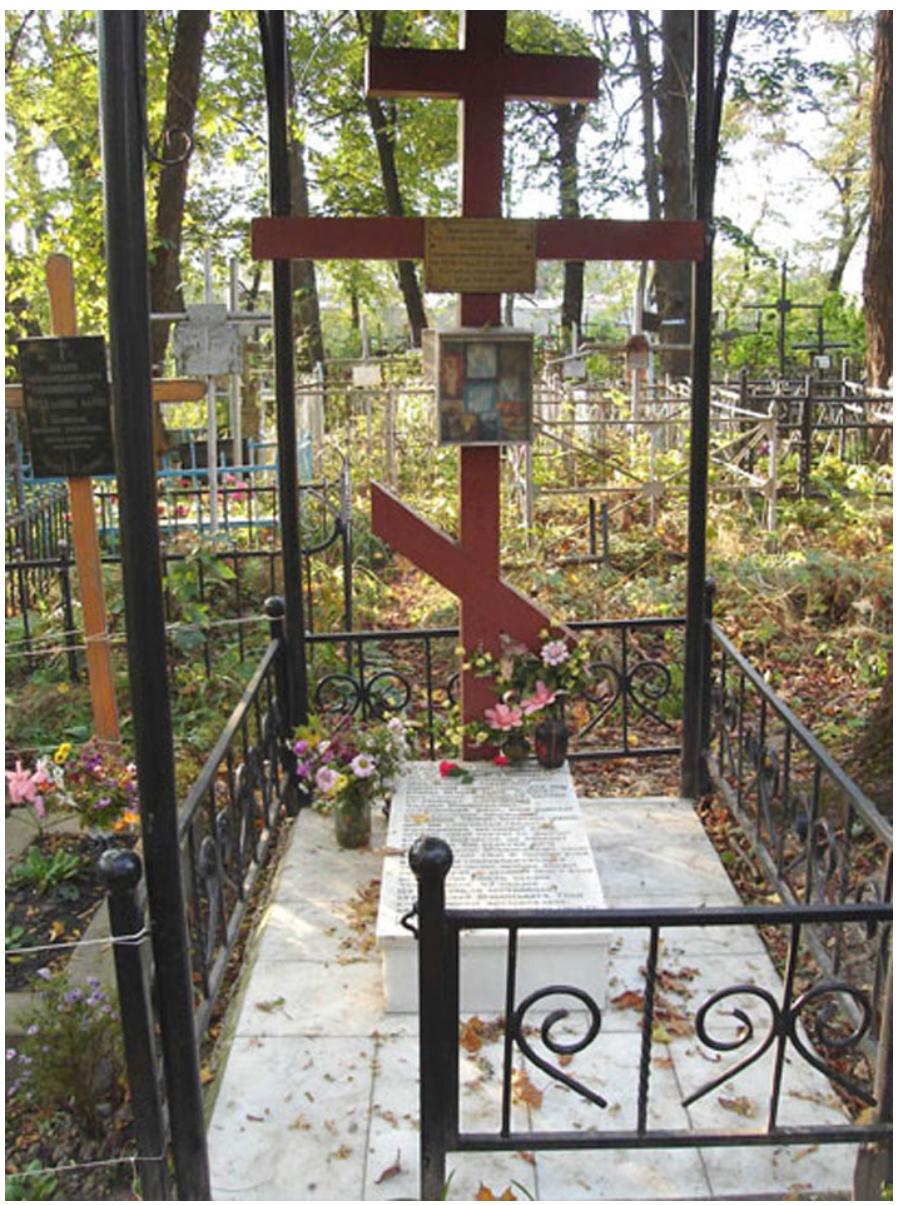

Figure 1. Grave of Andrei Iushchinskii, May 2011 (photo: Robert Weinberg)

Fig. 1). Each year on the anniversary of his murder hundreds of people journey to the cemetery where he is buried and claim that he died at the hands of Jews.

The website Der Stürmer pays homage to the Nazi newspaper of the same name published between 1923 and 1945 and includes a link to a web page devoted to the Beilis affair. ${ }^{15}$ Similarly, television shows, speeches, and books in parts of Europe and the Arab Middle East sometimes focus on the

\footnotetext{
15"Mendel Beilis: A Fiend That Stalked Children in 1912 Kiev," unsigned and undated web page sponsored by Judicial-Inc. Column, accessed September 23, 2012, http:// servv89pn0aj.sn.sourcedns.com/ gbpprorg/judicial-inc/mendel_beilis.htm. A link is posted on the website Der Stürmer, also sponsored by Judicial-Inc. Column, accessed September 23, 2012, http://der-stuermer.org/english/judical-inc.htm.
} 
blood libel as part of their anti-Israel propaganda. As late as the mid-1990s some clerics in Italy agitated for the return of the relics of a victim of a purported sixteenth-century ritual murder; one church publication in Turin devoted space to articles that urged readers to accept the veracity of ritual murder. ${ }^{16}$ As recently as April 2012, a member of the Hungarian parliament dredged up the Tiszaeszlár blood libel from the 1880s, claiming that "we do not know what happened." 17 While these expressions of antisemitism may be the provenance of fringe elements in these societies, the possibility still exists that political extremists could use the ritual murder accusation to fuel protests and other actions against Jews. Like the Protocols of the Elders of Zion, the infamous forgery and hoax that accuses Jews of engaging in a global conspiracy to dominate the world, the blood libel is alive and well in some parts of the world. ${ }^{18}$

The year 2013 is the centenary of the Beilis trial. The fact that the blood libel still resonates among people in different parts of the world should give us pause and prompt us to reflect on the lessons it holds for us in the early twenty-first century. The power and authority of the state have grown since the early twentieth century, and governments today possess control that the tsar's ministers could not even imagine. The ordeal of Mendel Beilis highlights the willingness of governments under siege to adopt desperate measures in the hope of holding onto power and reveals the capacity of the state to manipulate popular opinion and political outcomes. Literacy and education do not necessarily lead to the disappearance of ethnic, national, racial, and religious stereotypes. Indeed, as the two world wars of the twentieth century demonstrated, even so-called enlightened societies can fall victim to irrational and unsubstantiated ideas that have devastating consequences

\footnotetext{
${ }^{16}$ Tomasso Calio, "The Cult of the Alleged Ritual Murder Victims in the Second Half of the 20th Century in Italy," in Ritual Murder: Legend in European History, ed. Susanna Buttaroni and Stanisław Musiał, 225-45. In 1989 a Jewish woman with multiple personality disorder appeared on The Oprah Winfrey Show and told viewers that she had witnessed the ritual sacrifice of Jewish children by their parents. For an edited transcript of the interview, see Yori Yanover, "Vicki and the Devil," USA Jewish Stupid Email Tricks (blog), February 3, 2007, http://usajewish.blogspot.com/2007/02/vicki-and-devil.html.

${ }^{17}$ For a brief description of the speech, see "Hungarian Lawmaker: Jews Implicated in Blood Libel," Virtual Jerusalem, April 5, 2012, http://virtualjerusalem.com/news.php?Itemid=6621. ${ }^{18}$ The Protocols of the Elders of Zion first appeared in Russian in the early years of the twentieth century and gained worldwide popularity by World War I. Translated into many languages, the Protocols has become the bible of antisemites. Today, textbooks in the Arab Middle East describe the book as the truth, and in 2002 Egyptian television aired a miniseries inspired by the Protocols. For information on the Protocols, see Stephen Bronner, A Rumor about the Jews: Reflections on Antisemitism and the Protocols of the Learned Elders of Zion (New York, 2000); Norman Cohn, Warrant for Genocide: The Myth of the Jewish World Conspiracy and the Protocols of the Elders of the Zion (New York, 1967).
} 
for society. The ritual murder accusation teaches us about the toxic mix of antisemitism and politics and serves as a cautionary tale about the danger of ethno-religious hatreds for social and political stability. There is no guarantee that there will never be another case such as Beilis's, no matter how unlikely; the essays in this issue of Jewish History provide a historical perspective on a problem that continues to beset contemporary societies. 